\title{
A review on the advances of nitrifying biofilm reactors and their removal rates in wastewater treatment
}

\author{
Mona Chaali ${ }^{1}$, Mitra Naghdi ${ }^{1}$, Satinder Kaur Brar ${ }^{1 *}$, Antonio Avalos-Ramirez ${ }^{1,2}$ \\ ${ }^{1}$ Institut National de la Recherche Scientifique Centre - Eau Terre Environnement (INRS \\ ETE), 490 Rue de la Couronne, Québec, QC, G1K 9A9 Canada \\ ${ }^{2}$ Centre National en Électrochimie et en Technologie Environnementales (CNETE), \\ 2263 Avenue du Collège, Shawinigan, QC, G9N 6V8, Canada
}

(*Phone: 1418654 3116; Fax: 1418654 2600; E-mail: satinder.brar@ete.inrs.ca)

\begin{abstract}
:
Growing demand for efficient wastewater treatment systems leads to the development of new technologies. Biofilm-based reactors can be used for the treatment of a variety of wastewaters and these reactors are resistant against toxic environment. Bioreactors, such as sequencing batch biofilm, moving bed biofilm, and etc. are advanced techniques to treat various types of wastewaters with diverse operating conditions. Ammonium oxidizing bacteria (AOB), nitrite oxidizing bacteria (NOB) and Anammox (anaerobic ammonium oxidation) bacteria are reported to be responsible for nutrient removal. In recent decades, the performance of these systems is widely studied and compared for a number of wastewater treatment applications. In general, they are particularly suitable, for high-rate nitrification and nitrogen removal. The efficiency of these reactors has been confirmed in the laboratory and large-scale plants. Their efficiency depends on surface area of the biocarrier, the filling percent volume of biofilm carriers, organic loading and diffused aeration supply. $50 \%$ to $98 \%$ removal in chemical oxygen demand removal was reported for $<12 \mathrm{~h}$ of hydraulic retention time, $0.2 \mathrm{mg} / \mathrm{L}$ to $6.5 \mathrm{mg} / \mathrm{L}$ dissolved oxygen concentration and temperature range of $15-35^{\circ} \mathrm{C}$. Also, the ratio of nitrate to ammonium conversion was from 0.2 to 90 and $\mathrm{N}_{2}$ conversion was from $0 \mathrm{mg}$ to $8.5 \mathrm{mg}$. This review
\end{abstract}

This article has been accepted for publication and undergone full peer review but has not been through the copyediting, typesetting, pagination and proofreading process, which may lead to differences between this version and the Version of Record. Please cite this article as doi: $10.1002 / j$ ctb.5692

This article is protected by copyright. All rights reserved. 
studied each of these bioreactors in the removal of nutrients $(\mathrm{N}, \mathrm{P}$, and $\mathrm{O})$ from different wastewaters and compared them to conventional treatment. The review also includes the relevant studies on laboratory and pilot scales bioreactors to enhance their performance and reduce their costs.

Keywords: High ammonia wastewater, Biological reactor, Nitrification, Denitrification, Support media.

\section{Introduction}

Excess nitrogen loads have been recognized to be one of the serious causes which adversely affect the water quality ${ }^{1}$.Worldwide, there is an effort to reduce the emissions of nitrogen compounds to the surface waters and the atmosphere ${ }^{2}$. Ammonia is the most abundant inorganic nitrogen in various wastes and wastewaters, such as municipal wastewater, landfill leachate and livestock waste ${ }^{3}$. Excessive discharge of ammonia into the water environment can cause toxicity to aquatic organisms and hence eutrophication

${ }^{4}$. When aquatic ecosystems experience increased nutrients, the phytoplanktons and other photosynthetic plants growth explosively, commonly known as algal blooms ${ }^{5}$. The algal blooms limit the amount of dissolved oxygen (DO) required for respiration by other animal and plant species in the water ${ }^{6}$. In extreme cases, the anaerobic conditions encourage the growth of bacteria that produce toxins. Algal blooms are highly toxic and once the water reaches the anaerobic conditions, the growth of more toxic bacteria is promoted. The consequence is extensive deterioration of water quality and a decline in the availability of clean drinking water ${ }^{7}$. 
Ammonia can be removed by using physical, chemical and biological methods ${ }^{8}$, and sometimes in combinations of physical-chemical ${ }^{9}$ or biological-chemical ${ }^{10}$. The costeffectiveness of biological treatment has increased dramatically in the past few years since several processes for the biological removal of ammonia from wastewaters have become available ${ }^{11}$. For example, Rikmann et al, used undiluted reject stream from the dewatering stage of anaerobic sludge to start-up the autotrophic nitrogen removal in two pilot-scale configurations, nitritation-Anammox and deammonification. They observed that deammonification process produces up to $90 \%$ less excess sludge compared to denitrification and needs smaller process tanks which results in lower treatment costs ${ }^{12}$. Because biological nitrogen $(\mathrm{N})$ removal is more effective and relatively inexpensive, it has been adopted as compared to the physicochemical processes ${ }^{13}$. Conventional biological $\mathrm{N}$ removal has been widely applied at full scale to treat wastewater ${ }^{14}$, it is based on autotrophic nitrification and heterotrophic denitrification.

Nitrification (biological oxidation of ammonia to nitrate through nitrite) is an economical and sustainable means of ammonia removal as it eliminates the need for chemical addition ${ }^{15}$. The first nitrification step is $\mathrm{N}^{-\mathrm{NO}_{2}}{ }^{-}$formation (1), and the second step (2) is $\mathrm{N}-\mathrm{NO}_{3}{ }^{-}$formation ${ }^{16-18}$

$\mathrm{NH}_{4}^{+}+1.5 \mathrm{O}_{2} \longrightarrow \mathrm{NO}_{2}^{-}+2 \mathrm{H}^{+}+\mathrm{H}_{2} \mathrm{O}$

$\mathrm{NO}_{2}^{-}+0.5 \mathrm{O}_{2} \longrightarrow \mathrm{NO}_{3}^{-}$

Nitrifiers are slow-growing microorganisms. Growth in suspension requires long residence times, or diluted feed streams (a situation frequently found in domestic wastewater treatment processes) ${ }^{19-21}$. In these cases, biofilms can represent an effective solution to successfully retain biomass in the reactors ${ }^{22}$. Several technologies based on 
the biofilm have been developed as alternatives to the traditional wastewater treatment ${ }^{23}$, ${ }^{24}$. Biofilm reactors represent the primary means to harness the usefulness of biofilms for the water treatment, such as $\mathrm{N}$ removal ${ }^{25}$. For instance, Zekker et al. reported that biological $\mathrm{N}$ removal efficiency in MBBR is dependent on temperature and toxic nitrite concentrations. A high nitrite production (100 $\left.\mathrm{mg} \mathrm{NO}_{2}{ }^{-\mathrm{N}} / \mathrm{L}\right)$ has an inhibitory effect on ammonium oxidizing bacteria (AOB). Also, they found that AOB populations increased in abundance during reactor operation when the temperature was decreased from $26{ }^{\circ} \mathrm{C}$ to $20{ }^{\circ} \mathrm{C}{ }^{26}$. In a similar research work, Raudkivi et al. reported that nitrite has a limiting effect on Anammox process due to nitrite toxicity ${ }^{27}$.

Biofilm processes are commonly used for nitrification ${ }^{28}$. In recent years, many systems have been tested and applied, mainly for the industrial wastewater, to pilot and full-scale plants, such as moving bed biofilm reactors, sequencing biofilm batch reactor, and membrane bioreactors ${ }^{24,29}$. Different types of nitrifying bioreactors are summarized in Table 1. This review will discuss the most widely used nitrifying bioreactor systems in recent decades which have been proved to be very efficient.

\section{Biological nitrogen removal}

In conventional treatments, the biological removal of nitrogen from wastewater requires a two-step process: autotrophic nitrification and heterotrophic denitrification. During nitrification $\mathrm{NH}_{4}{ }^{+}$is converted to $\mathrm{NO}_{2}{ }^{-}$and further to $\mathrm{NO}_{3}{ }^{-}$with molecular oxygen as the electron acceptor. The oxidation of ammonium is generally attributed to Nitrosomonas europaea, and the oxidation of nitrite to Nitrobacter agilis ${ }^{30}$.

In the second step, denitrification is generally performed by a heterotrophic bioconversion process under anaerobic (anoxic, precisely) conditions. The oxidized 
nitrogen compounds $\left(\mathrm{NO}_{2}{ }^{-}\right.$and $\left.\mathrm{NO}_{3}{ }^{-}\right)$are reduced to gaseous dinitrogen by heterotrophic microorganisms that use nitrite and/or nitrate instead of oxygen as electron acceptors and organic matter carbon and energy source ${ }^{13}$. This process is performed by various chemoorganotrophic, lithoautotrophic, and phototrophic bacteria and some fungi, especially under oxygen-reduced or anoxic conditions ${ }^{31}$.

Biological nitrogen removal proceeds slowly because the microorganisms responsible for the removal reactions grow slowly. In addition, the operational control of aerobic and anaerobic conditions needed for nitrification and denitrification, respectively, can be difficult. To cope with these problems, various kinds of bioreactors have been studied for enhancing the efficiency of nitrogen removal ${ }^{30}$. Moreover, generally, the conventional biological nitrogen removal is used for treating wastewaters with relatively low nitrogen concentrations (total nitrogen concentration less than $100 \mathrm{mg} \mathrm{N} / \mathrm{L}$ ) ${ }^{14}$. Several recent studies are beginning to focus on new biological nutrient removal processes, including single reactor system for high ammonia removal over nitrite (SHARON), anaerobic ammonium oxidation (ANAMMOX) ${ }^{32,33}$ and completely autographic nitrogen removal over nitrite (CANON) systems ${ }^{31}$.

These new processes are based on the partial nitrification of ammonium into nitrite combined with the anaerobic oxidation of ammonium. Briefly, SHARON process involves the partial conversion of ammonium to nitrite; ANAMMOX presents the anaerobic ammonium oxidation process and CANON process removes nitrogen completely autographic by nitrite in a reactor under limited oxygen conditions. Their most prominent advantages are the reduction of energy demand, the absence of external carbon addition and the lower production of sludge compared to conventional treatment. 
Moreover, they offer potential for improving the efficiency of nutrients removal. However, these new technologies meet some challenges for introduction and application in a large-scale plant and need to be optimized for better treatment of contaminated water in high-strength wastewater ${ }^{31,34,35}$.

\section{Membrane biofilm reactors}

\subsection{Moving bed biofilm reactor $(\mathrm{MBBR})$}

Moving bed biofilm reactor (MBBR) has been established as a very effective technology for nitrogen removal in wastewater treatment ${ }^{36}$. It has been successfully used for municipal and industrial wastewater including pulp and paper industry wastewater, poultry processing wastewater and dairy wastewater ${ }^{37-40}$. MBBR is being considered as an upgrade option for an increasing number of wastewater treatment facilities due to its small footprint and feasible operation ${ }^{41}$. This process relies on the use of moving carriers in which microorganisms' form biofilms. Thus, the slow-growing microorganisms, such as nitrifying bacteria can be retained in the system without being washed out. However, application of MBBR in wastewater treatment has received much attention now due to their high efficiency ${ }^{42}$. The possible experimental setup of MBBR is shown in Figure 1. The objective of the MBBR systems is to achieve the growth of the biomass as a biofilm on small carriers, which have a lower density than water ${ }^{39}$. The carriers are continuously kept in the tank and are able to move freely in the reactor without sludge recycling. The systems include a submerged biofilm reactor and a liquid-solid separation unit 43,44 . Nitrification in moving bed biofilm reactor has been studied to identify the key limiting conditions. In particular, the key factors include the effect of the bulk oxygen concentration, temperature, ammonia concentration and the organic loading rate ${ }^{45}$. 
According to a study carried out by Wang et al., the nitrification in MBBR depends on DO in the reactor. The DO diffusion through the biofilm was the rate-determining step for media nitrification. The highest nitrogen removal efficiency $(89.1 \%)$ was reached when the DO was maintained at $2 \mathrm{mg} / \mathrm{L}$. At lower DO concentrations ( $<1 \mathrm{mg} / \mathrm{L})$, anoxic conditions prevailed and ammonia concentration in the effluent increased ${ }^{4}$. Generally, a high bacterial activity and growing biofilm is the most cause of rapid decrease of oxygen concentration $^{46}$.

The MBBR technology promotes biofilm attachment and growth on engineered carriers that are maintained in constant suspension. The attached biofilms are maintained and protected from abrasion with other carriers in the interior spaces of the MBBR carriers ${ }^{15}$. Nitrifying biofilms attached to MBBR carriers have demonstrated highly diverse microbial populations ${ }^{47}$. Several parameters may affect the efficiency of the MBBR such as the percent of media provided in the reactor and the organic loading (to allow the free carrier suspension, the percentage of reactor volume occupied with carriers in empty tank normally varies from $60 \%$ to $70 \%)^{48}$. Young et al. stated that the MBBR performance depends on the loading rate as well as the carrier type. The carriers play an important role in the formation of microbial community within the biofilm. According to their observations, the pore spaces of carriers with the higher surface area to volume (500 $\mathrm{m}^{2} / \mathrm{m}^{3}$ to $900 \mathrm{~m}^{2} / \mathrm{m}^{3}$ ) has potential to become clogged at severe conditions in synthetic wastewater ${ }^{49}$. Different types of carriers have been used in MBBR systems such as polyethylene plastic, polyurethane sponge, granular activated carbon, etc. ${ }^{50,51}$. MartínPascual et al. used commercial carriers (Aqwise, Kaldnes, and BIOCONS) in MBBRs for treatment of municipal wastewater and obtained chemical oxygen demand (COD) 
removal of $56 \%, 58 \%$ and $46 \%$, respectively ${ }^{52}$. Among the carriers, sponge exhibited an ideal attached growth media due to its high porosity and immobilization tendency of biomass on the surface and inside of the sponge pores ${ }^{53,54}$. Zhang et al. used sponge cube with a specific surface area of $0.846 \mathrm{~m}^{2} / \mathrm{g}$ for treatment of synthetic wastewater in MBBR ${ }^{53}$. Similarly, Nguyen et al. studied the organic removal in a bioreactor with sponge cube as a carrier. They obtained over $90 \%$ removal in total organic carbon (TOC), 95\% removal in COD, 90\% removal in total phosphorus and 65\% removal in total nitrogen aerobic conditions ${ }^{55}$. Deng et al. used a sponge modified carriers with a specific surface area of $500 \mathrm{~m}^{2} / \mathrm{m}^{3}$ for treatment of domestic wastewater and observed an improvement in the effluent quality and nutrient removal, compared to the MBBR using plastic carriers ${ }^{54}$. Chen et al. coated the inside and outside of a hard polyethylene ring with a sponge to use as a carrier in MBBR. COD and ammonium removal reached $99 \%$ and $93 \%$, compared to commercial carrier $(74 \%$ and $40.0 \%){ }^{56}$. Chu et al used a biodegradable polymer as biofilm carriers in a MBBR for simultaneous nitrification and denitrification in wastewater. They obtained $74.6 \%$ total nitrogen removal efficiency on average ${ }^{57}$. They also studied the performance of two types of carriers namely polyurethane foam and polycaprolactone on the removal of nitrogen and organics from wastewater. The polyurethane foam exhibited higher removal for TOC and ammonium (90 and $65 \%$ versus $72 \%$ and $56 \%$, respectively) ${ }^{58}$.

The biofilm growth can be affected by the constant collision and shear of media, the effective internal surface area is an important design factor ${ }^{36}$. Trapani et al. reported that the fill fraction is an important parameter which must be considered depending on the treatment objectives. They concluded that fill fraction is responsible for the creation of 
competition between suspended and attached biomass and the importance of suspended solids which can decrease the MBBR efficiency. However, low suspended biomass can decrease the MBBR nitrogen removal efficiency due to their major role in enzymatic hydrolysis and bio-flocculation in the reactor ${ }^{59}$. Hem et al. reported that nitrification rates using biofilm reactors are straightly influenced by the DO concentration, total ammonium nitrogen (TAN) concentration, organic load, temperature and $\mathrm{pH}^{45,60}$.

As shown by Monfet et al., anaerobic AOB process has been widely used for nutrient recovery and it has recently considered as a novel route for $\mathrm{N}$ removal in $\mathrm{MBBR}$ systems $^{61}$. Szatkowska et al. studied a simultaneous partial nitritation/Anammox process in MBBR for completely autotrophic nitrogen removal. They reported that bacterial culture was able to perform simultaneously two processes, Anammox and partial nitritation in a single-stage reactor at the technical-scale pilot plant. The maximum nitrogen removal rate $\left(1.45 \mathrm{~g} \mathrm{~N} \mathrm{~m}^{-2} \mathrm{~d}^{-1}\right)$ was obtained for the pilot plant during the 1-year experimental period ${ }^{62}$. In another study by the same authors, it has been proven that biofilm entrained Anammox in MBBR will survive at temperatures below the range 30 ${ }^{\circ} \mathrm{C}$ to $35^{\circ} \mathrm{C}{ }^{63}$.

Finally, MBBR has been recognized as an ideal process for nitrification, it allows a good bacterial proliferation due to the carriers while allowing to sustain a high-density population of nitrifying bacteria ${ }^{36}$.

\subsection{Membrane aerated biofilm reactor (MABR)}

Membrane aerated biofilm reactors (MABR) are commonly understood as the combination of membrane filtration and biological treatment using activated sludge (AS) where the membrane primarily serves to replace the clarifier in the wastewater treatment 
system ${ }^{64}$. The MABR is an emerging technology for wastewater treatment. It is based on pressurized membranes that supply a gaseous substrate to a biofilm formed on the membrane exterior. MABR behaves differently from conventional biofilms due to the counter-diffusion of substrates. They are uniquely suited for numerous treatment applications, including the nitrogen removal when oxygen is supplied ${ }^{23}$. Martin et al. observed that complete nitrogen removal (100\%) can be achieved by membrane biofilm reactors ${ }^{23}$. Figure 2 shows a schematic diagram of the laboratory-scale MABR that is used for nitrification.

Recently, there has been a growing interest in reactor systems using MABRs because of their several advantages over conventional systems, their ability to remove nitrogen and for their efficient potential low energy oxygen transfer ${ }^{65}$. MABR represent a new technology for aerobic wastewater treatment. Oxygen diffuses through a gas permeable membrane into the biofilm where oxidation of pollutants, supplied on the biofilm side of the membrane, takes place ${ }^{66}$. In the MABR, the biofilm grows on an oxygen-permeable membrane. It allows a simultaneous nitrogen and organics removal ${ }^{67}$. Hibiya et al. reported $90 \%$ removal of total nitrogen from modified domestic wastewater up to 150 days by using the MABR ${ }^{67}$. COD and nitrogen removal rates obtained from published MABR trials are consistently higher than any other wastewater treatment technologies processes in current use, such as MBBRs ${ }^{68}$. Figure 3 shows schematically the diffusive and advective fluxes of oxygen and soluble wastewater constituents in an MABR.

In addition, MABRs attain higher gas transfer rates compared to conventional bubble aeration. The simultaneous removal of COD and nitrogen from wastewater is ensured by MABR with smaller tank sizes with significant energy savings and specific microbial 
communities ${ }^{69}$. Wang et al. reported that the ammonium removal efficiency of the MABR was increased from $50 \%$ to $90 \%$ by increasing the transmembrane pressures from 0.002 to $0.02 \mathrm{MPa},{ }^{69}$. Tian et al. operated an MABR at several aeration pressures $(0.1$, 0.15 , and $0.2 \mathrm{MPa})$ with a same hydraulic retention time (HRT) $(24 \mathrm{~h})$ for the treatment of wastewater. By increasing the aeration pressure, COD and ammonium concentrations of effluent decreased, and reached to the lowest values of around $75 \mathrm{mg} / \mathrm{L}$ and $0.4 \mathrm{mg} / \mathrm{L}$, for aeration pressure of $0.2 \mathrm{MPa}$. Higher air supply pressure could be in favor of nitrification rate, but might be limiting the denitrification process to a certain degree ${ }^{70}$. The aeration pressure also play an important role in microbial stratification and can affect nitrification and denitrification ${ }^{71,72}$. Li et al. demonstrated that increasing aeration pressure from 0.005 to $0.03 \mathrm{MPa}$, led to increase in the COD/N ratio from 4 to $7^{73}$. Similarly, Syron et al. observed that when oxygen pressure was increased from 0.015 to $0.02 \mathrm{MPa}$, complete oxidation to nitrate happened and oxygen transfer efficiency was increased from $20 \%$ to $80 \%^{74}$.

The simultaneous nitrification and denitrification are allowed when the oxygen delivery through the membrane is precisely controlled ${ }^{67}$. According to a study carried out by Yamamoto et al. a handling trans-membrane air pressure provision can control the nitrification rates in MABR. They also reported that the ratio of the oxygen flux to the ammonia flux was the crucial parameter for controlling nitrogen conversion ${ }^{75}$. Lackner et al. demonstrated that the oxygen transfer rate and partial pressure can determine the success of nitrification in MABRs. Furthermore, high oxygen concentration at the biofilm base compromised the ability to optimize reactor operation for high nitrification efficiency by adjusting the oxygen flux via the gas pressure ${ }^{76}$. Very high specific 
nitrification rates with close to $100 \%$ oxygen conversion efficiency in a sealed end hollow fiber MABR was reported by Brindle and Stephenson ${ }^{77,78}$. Due to thin biofilms and a high bulk liquid DO concentration, it is likely that complete oxygen penetration of the biofilm occurred which resulted in specific nitrification rates of $13 \mathrm{~kg} \mathrm{NH}_{4}-\mathrm{N} \mathrm{kg} /(\mathrm{SS}$ day), significantly higher than most other nitrification processes. If the biofilm thickness can be kept low, then the volumetric nitrification rate is only limited by the specific membrane surface area available for the biofilm attachment ${ }^{77,78}$. Downing and Nerenberg found that the ammonium flux and nitrite accumulation increased with increasing transmembrane operation pressure and that shortcut nitrification can effectively be controlled by varying DO at the membrane surface ${ }^{79}$. One of the applications of MABRs is to control the rate of nitrification and, if possible, create conditions promoting simultaneous nitrification and denitrification ${ }^{4}$. One of the claimed advantages of MABRs is that they can be used for simultaneous nitrification and organic removal in a single reactor. Low rates of nitrification but very high organic carbon oxidation were reported by several researchers in studies where a washing procedure was employed to detach excess biomass ${ }^{80,81}$. MABR studies by Miyahara et al. showed that the thickness of a denitrifying layer affected the oxygen transfer rate and that it was necessary to control the biofilm thickness by sloughing in order to maintain oxygen transfer rates high enough for effective nitrification ${ }^{82}$.

\subsection{Biofilm airlift suspension reactor (BASR)}

The biofilm airlift suspension reactor (BASR) is an attached growth system that consists of two concentric tubes. Air is introduced at the bottom of the inner tube of the airlift part. A schematic representation of the BASR is given in Figure 4. 
The introduction of air creates a difference between the fluid density in the riser (rising column) and that in the downcomer. As a consequence, it creates mixing between the liquid and the carrier. In addition, air added to the reactor provides the oxygen needed to degrade the substrate. On top of the airlift part, there is a three-phase separator which is used to retain the biofilm particles in the reactor ${ }^{83}$. Airlift technology reactor represents a potential solution where the high oxygen levels in the stream assure higher efficiency and low odor impact. However, the design and management of these less common treatment plants can require a numerical tool to analyze and control the different processes involved ${ }^{84}$. Several mathematical models were developed to link the substrate flux into the biofilm to the fundamental mechanisms of substrate utilization and mass transport. Nitrification can be performed efficiently in BASR ${ }^{85}$.

In biofilm systems, the maximum volumetric ammonia conversion is usually limited by the liquid-biofilm or the gas-liquid oxygen mass transfer rate. BASRs have a relatively high gas-liquid mass transfer of oxygen and a high specific area due to the growth of a biofilm on small suspended carrier particles. This makes it possible to reach high volumetric ammonia conversions ${ }^{2,21}$. The biofilm airlift suspension reactor is well suited for nitrification. This compacted reactor combines a high nitrification capacity and a high biomass concentration with a low ground area occupied because the biomass settler is integrated on top of the reactor ${ }^{21}$. The inherent benefits of the BASR are attributed to its high oxygen transfer efficiency, a high concentration of immobilized biomass on the solid carrier, and excellent mixing and substrate transfer abilities ${ }^{83}$. Experimental observations of Garrido et al. have shown that it is possible to obtain full ammonium conversion with approximately $50 \%$ nitrate and $50 \%$ nitrite in the effluent of a biofilm 
airlift suspension reactor. With oxygen concentrations between $1 \mathrm{mg} / \mathrm{L}$ and $2 \mathrm{mg} / \mathrm{L}$, a maximum nitrite accumulation of $50 \%$ was reached ${ }^{86}$. According to Picioreanu et al. controlling the oxygen concentration seems to be the most practical method to obtain optimal nitrification in BAS reactors. They concluded that varying the oxygen concentration was the most practical method to obtain partial nitrification in BASR since this can be done by varying the superficial gas velocity or by partial recirculation of the off-gas ${ }^{87}$. In a study done by Van Benthum et al., they concluded that in BASR, it is possible to have process and oxygen control to force the nitrification, thereby saving needed $\mathrm{COD}^{20}$.

\subsection{Sequencing batch biofilm reactor (SBBR)}

The sequencing batch biofilm reactor (SBBR) system is a biofilm technology which has attracted much attention because of its ability to take advantage of being both a biofilm reactor and a sequencing batch reactor ${ }^{88}$. The SBBR system shows higher biomass concentration in the reactor, with corresponding higher specific removal rates and less sludge production, higher volumetric loads, increased process stability towards shock loadings and biomass enrichment of slow-growing organisms, such as nitrifiers than the competing technologies ${ }^{89,}{ }^{90}$. The SBBR is a fill and draw reactor where the biomass is fixed on a support medium. In this system, wastewater is added to a single batch reactor and treated to remove undesirable components before discharge ${ }^{89}$. As compared to most activated sludge sequencing batch reactor (SBR) systems, which require the settling period to separate activated sludge, the SBBR system typically does not need settling and sludge recycling equipment, still maintaining high microbial concentrations inside the reactor ${ }^{91}$. The schematic of sequencing batch reactor mechanism is shown in Figure 5. 
Accordingly, the SBBR has been adopted to remove nitrogen and phosphorus simultaneously from many types of wastewater ${ }^{92}$. Jin et al. reported that the total nitrogen removal was significantly influenced by nitrogen loading rate and better nitrogen removal was achieved at higher $\mathrm{C} / \mathrm{N}$ ratios. The average of nitrogen removal efficiencies was varied between $65.4 \%$ to $81.0 \%{ }^{92}$. Many successful cases of partial nitrification have been reported for SBBR. There are few reports about partial nitrification conducted in an intermittently aerated SBBR ${ }^{93}$. SBBRs are spatially heterogeneous, providing space for both, aerobic and anaerobic processes. They are well suited for nitrification since the attached growth of the slow-growing nitrifying bacteria protected them from washout ${ }^{94}$. Recently, an SBBR was designed for efficient enhanced biological phosphorus and nitrogen removal and is successfully scaled up to the pilot scale $^{95}$. The implementation of nitrification into this type of reactor is a challenging but desired step in saving reactor volume and costs. As for nitrification and phosphorus removal, both processes consume oxygen, hence the organisms in such a system are potentially subjected to competition for oxygen ${ }^{96}$.

Nitrification and nitrifying bacteria were always restricted to the periodically oxic biofilm surface. Both activity and population size increased significantly with higher ammonium concentrations. Nitrification always showed a delay after the onset of aeration, most likely due to competition for oxygen by the co-existing phosphorus accumulating and other heterotrophic bacteria during the initial aeration phase. This view is also supported by comparing oxygen penetration and oxygen uptake rates under low and high ammonium conditions. Therefore, simultaneous nitrification and phosphorus removal in a phosphorus removing SBBR appear to be only possible with a sufficiently longer oxic 
period to ensure oxygen availability for nitrifiers ${ }^{97}$. Malaspina et al. found that SBBR showed high N-removal capacity with excellent sludge settling properties. On the other hand, organic carbon removal efficiency with nitrate was lower than with oxygen. Also, batch biofilm nitrification was very effective, with very high nitrification rates ${ }^{98}$.

In conventional biofilm reactors, autotrophic nitrifying organisms may be excluded from the oxic layer of the biofilm due to the faster growth of heterotrophs. As a result, substantial nitrification only occurs when the carbon substrate loading rate of the wastewater is low ${ }^{66}$. Zuniga and Martinez reported an efficient phosphate removal and complete nitrification using SBBR ${ }^{99}$. According to Wei et al., partial nitrification was successfully achieved and maintained in an SBBR ${ }^{100}$. Although fixed-bed reactors have been shown to be capable of treating a variety of wastewaters, the real-world applications of SBBRs are limited due to several drawbacks of the system itself. For example, the fixed bed is easily clogged ${ }^{101}$. Recently, it was suggested that moving bed biofilm reactors (MBBRs) could be operated in a sequencing batch mode, in order to benefit from the advantages of both processes (Table 2) ${ }^{102}$. The use of moving bed sequencing batch reactor (MBSBR) which combines suspended growth and attached growth processes in a single reactor to remediate nitrogen bearing wastewater has gained increasing interest among the researchers ${ }^{103}$. Tan et al. studied the performance of total nitrogen removal by MBSBR and removal efficiency was in the range of $64 \%$ to $80 \%$. He reported that influent feed has a positive effect on nitrogen removal ${ }^{35,103}$.

\section{Operating conditions in biofilm reactors}

The influence of operational parameters on the nitrification of the biofilm is illustrated in Table 3. Factors, such as pH, DO, HRT and temperature can affect the TN, COD and 
total phosphor removal. Pandey and Sarkar observed that by increasing HRT from $18 \mathrm{~h}$ to $72 \mathrm{~h}$, the COD removal efficiency increased from $61 \%$ to $89 \%{ }^{104}$. Kim et al. observed that by increasing HRT from $3 \mathrm{~h}$ to $4 \mathrm{~h}$, nitrification efficiency was increased from $75 \%$ to $82 \%{ }^{105}$. Brosseau et al. studied the performance of bioreactors at $10{ }^{\circ} \mathrm{C}$ and $20{ }^{\circ} \mathrm{C}$ and reported that the decreasing the temperature from $20{ }^{\circ} \mathrm{C}$ to $10{ }^{\circ} \mathrm{C}$ caused a significant reduction of $15-41 \%$ of COD removal efficiency ${ }^{106}$. Li et al. reported that supplying sufficient DO $(5 \mathrm{mg} / \mathrm{L})$ and avoiding the negative effect of the aeration shear stress help to form a biofilm with enough thickness ${ }^{107}$.

The polymerase chain reaction and denaturing gradient gel electrophoresis (PCR-DGGE) is a method for identifying the most abundant bacteria in the bioreactors system ${ }^{108}$. Conventional PCR can provide information on the presence of certain microorganisms but does not provide any information on abundance. Recently, quantitative real-time PCR (qPCR) was developed to provide quantitative information on the abundance of a certain microorganism using fluorescently labeled probes and dyes ${ }^{109}$. Pellicer-Nacher et al. studied the abundance of functional microbial guilds after 630 days of MABR operation via $\mathrm{qPCR}$ techniques. Their results revealed $0.2 \%, 5.4 \%$ and $25 \%$ relative abundance for $\mathrm{NOB}, \mathrm{AOB}$ and anaerobic ammonium oxidizing bacteria, respectively ${ }^{110}$. Torresi et al. studied the effect of thickness of biofilm on the microbial community through $\mathrm{qPCR}$ technique. Their results showed that the biofilm with the highest thickness $(500 \mu \mathrm{m})$ achieved the highest constants for specific biotransformation rate and the biofilm with least thickness $(50 \mu \mathrm{m})$ showed the highest nitrification rate ${ }^{111}$.

\section{Cost factors}


Operational cost savings are necessary for the membrane to be competitive. It can be reached through reduction of energy consumption, the elimination of brine release, employing low-cost carrier, etc. ${ }^{54,112}$. Nerenberg et al. reported that a major advantage of the membrane biofilm reactor is low energy requirement ( $86 \%$ more energy efficient than conventional system). Membrane durability, membrane cost, and membrane removal fluxes are other factors affecting the cost saving. Without full-scale data, it is difficult to quantify the savings, but data obtained from the pilot scale and modeling can be used as a primary approximation. ${ }^{112,113}$. In an MABR, aeration is very energy intensive and accounts for $45-75 \%$ of plant energy costs ${ }^{114}$. However, MABR can outperform conventional treatment in terms of energy efficiency and pollutant removal rate due to high oxygen transfer efficiencies and smaller aeration equipment. Operating MABR with pure oxygen requires up to five times less membrane area compared to operating with air which provides savings in capital investment ${ }^{74}$. Also, Lin et al. emphasized on the costeffectiveness of MABR compared to conventional biological treatment because of lower emission of volatile pollutants and lower operating cost. The effectiveness of membranes in MABR is twofold compared to conventional bubbled diffuser reactors, due to immobilizing microorganisms on carriers and less required aeration ${ }^{115}$. Hem et al. reported the higher sensitivity of nitrification in the MBBR to the variation of oxygen concentration compared to other biofilm reactors. Due to this sensitivity, the nitrifying moving bed reactor is generally operated at a higher oxygen concentration to reduce the reactor size and consequently, the construction costs ${ }^{45,54}$. Cost of membrane replacement is the main economic obstacle to commercial scales. However, the decreasing trend observed in the cost of the commercial membrane in recent years and also increase in the 
cost of energy is promising to make the membrane bioreactors more attractive. In conclusion, more laboratory scale and recent pilot scale data are required to generate realworld data for economic evaluation.

\section{Conclusion and Future work}

The conventional process for nitrogen removal from wastewater comprised of autotrophic nitrification and heterotrophic denitrification. Due to high consumption of energy and carbon source, more research is needed for development and implementation of economically efficient processes. The different biofilm reactors, such as moving bed reactor, membrane aerated biofilm reactor, biofilm airlift suspension reactor and sequencing batch reactor are widely used for a number of wastewater treatment applications. To date, they are particularly suitable due to their high-rate nitrification and nitrogen removal in the laboratory and large-scale demonstrations. There are a large number of reports comparing the performance of biofilm reactors as a promising technology to achieve high efficiency in nutrient removal. Briefly, the sequencing batch biofilm reactor is a very useful system due to its low cost and the flexibility of its operation. The moving bed biofilm reactor is also an equally efficient system since it promotes the development of biomass and does not produce a large amount of sludge compared to other systems. The membrane aerated biofilm reactor provides an optimal concentration of oxygen to the biomass. And finally, the biofilm airlift suspension reactor is a system that allows a high mass and oxygen transfer rate and it has a high nitrification capacity.

Recent investigations on the modeling and engineering aspects of different biofilm reactors indicated the significance $(\mathrm{P}<0.05)$ of the placement of individual microbial 
layers in biofilms. Understanding the processes affecting the placement of these individual layers are required for reactors' scale-up and also for the selection of the optimum conditions.

Despite the commercial implementation of biofilm reactors for wastewater treatment and production of value-added products, the knowledge of fundamentals of biofilm formation and physicochemical properties of a biofilm is required to run the reactor at optimum conditions. Moreover, the stable productivity of bioreactor can only be achieved through optimum reactor design and by improving solid supports for homogeneous distribution of the biofilm. In addition to the above-mentioned significant factors, other parameters, such as wastewater characteristics, biofilm composition/structure, and carrier-biofilm interaction must be considered for each product and microorganism to skip the restrictions imposed by diffusion, biomass activity, etc.

\section{Acknowledgments}

The authors are sincerely thankful to the Natural Sciences and Engineering Research

Council of Canada (Discovery Grant 355254 and Strategic Grants) for financial support.

The views or opinions expressed in this article are those of the authors. References:

1. Birgand F, Skaggs RW, Chescheir GM and Gilliam JW, Nitrogen Removal in Streams of Agricultural Catchments-A Literature Review. Critical Reviews in Environmental Science and Technology 37: 381-487 (2007).

2. Qiu C, Zhang D, Sun L and Wen J, Purification of high ammonia wastewater in a biofilm airlift loop bioreactor with microbial communities analysis. World Journal of Microbiology and Biotechnology 31: 49-57 (2015).

3. Bassin JP, Dezotti M and Sant'Anna Jr GL, Nitrification of industrial and domestic saline wastewaters in moving bed biofilm reactor and sequencing batch reactor. Journal of Hazardous Materials 185: 242-248 (2011).

4. Wang XJ, Xia SQ, Chen L, Zhao JF, Renault NJ and Chovelon JM, Nutrients removal from municipal wastewater by chemical precipitation in a moving bed biofilm reactor. Process Biochemistry 41: 824-828 (2006). 
5. Shumway SE, A Review of the Effects of Algal Blooms on Shellfish and Aquaculture. Journal of the World Aquaculture Society 21: 65-104 (1990).

6. Anderson DM, Glibert PM and Burkholder JM, Harmful algal blooms and eutrophication: nutrient sources, composition, and consequences. Estuaries 25: 704-726 (2002).

7. Hallegraeff GM, Harmful algal blooms: a global overview. Manual on harmful marine microalgae 33: 1-22 (1995).

8. Yang Y, Li X, Yang X and He Z, Enhanced nitrogen removal by membraneaerated nitritation-anammox in a bioelectrochemical system. Bioresource Technology 238: 22-29 (2017).

9. Klein K, Kattel E, Goi A, Kivi A, Dulova N, Saluste A, Zekker I, Trapido M and Tenno T, Combined treatment of pyrogenic wastewater from oil shale retorting. Oil Shale 34: 82 (2017).

10. Klein K, Kivi A, Dulova N, Zekker I, Mölder E, Tenno T, Trapido M and Tenno $\mathrm{T}$, A pilot study of three-stage biological-chemical treatment of landfill leachate applying continuous ferric sludge reuse in Fenton-like process. Clean Technologies and Environmental Policy 19: 541-551 (2017).

11. Schmidt I, Sliekers O, Schmid M, Bock E, Fuerst J, Kuenen JG, Jetten MSM and Strous M, New concepts of microbial treatment processes for the nitrogen removal in wastewater. FEMS Microbiology Reviews 27: 481-492 (2003).

12. Rikmann E, Zekker I, Tenno T, Saluste A and Tenno T, Inoculum-free start-up of biofilm- and sludge-based deammonification systems in pilot scale. International Journal of Environmental Science and Technology 15: 133-148 (2018).

13. Ahn Y-H, Sustainable nitrogen elimination biotechnologies: A review. Process Biochemistry 41: 1709-1721 (2006).

14. Van Hulle SWH, Vandeweyer HJP, Meesschaert BD, Vanrolleghem PA, Dejans $\mathrm{P}$ and Dumoulin A, Engineering aspects and practical application of autotrophic nitrogen removal from nitrogen rich streams. Chemical Engineering Journal 162: 1-20 (2010).

15. Young B, Delatolla R, Kennedy K, Laflamme E and Stintzi A, Low temperature MBBR nitrification: Microbiome analysis. Water Research 111: 224-233 (2017).

16. Grabínska-Łoniewska A, Denitrification unit biocenosis. Water Research 25: 1565-1573 (1991).

17. Tam N, Wong Y and Leung G, Effect of exogenous carbon sources on removal of inorganic nutrient by the nitrification-denitrification process. Water Research 26: 1229-1236 (1992).

18. Akunna JC, Bizeau $\mathrm{C}$ and Moletta R, Nitrate and nitrite reductions with anaerobic sludge using various carbon sources: glucose, glycerol, acetic acid, lactic acid and methanol. Water Research 27: 1303-1312 (1993).

19. Nicolella $C$, Van Loosdrecht $M$ and Heijnen J, Wastewater treatment with particulate biofilm reactors. Journal of biotechnology 80: 1-33 (2000).

20. Van Loosdrecht MCM, Van Benthum WAJ and Heijnen JJ, Integration of nitrification and denitrification in biofilm airlift suspension reactors, in Water Science and Technology, pp. 97-103 (2000).

This article is protected by copyright. All rights reserved. 
21. Van Benthum WAJ, Garrido JM, Mathijssen JPM, Sunde J, Van Loosdrecht MCM and Heijnen JJ, Nitrogen removal in intermittently aerated biofilm airlift reactor. Journal of Environmental Engineering 124: 239-248 (1998).

22. Wang J, Liu W and Liu T, Biofilm based attached cultivation technology for microalgal biorefineries-A review. Bioresource Technology (2017).

23. Martin KJ and Nerenberg R, The membrane biofilm reactor (MBfR) for water and wastewater treatment: Principles, applications, and recent developments. Bioresource Technology 122: 83-94 (2012).

24. Viotti P, Luciano A, Mancini G and Torretta V, A wastewater treatment using a biofilm airlift suspension reactor with biomass attached to supports: a numerical model. International Journal of Environmental Science and Technology 11: 571588 (2014).

25. De Feo G, Carbon and nitrogen removal from low-strength domestic wastewater with a two-stage submerged biological filter. Journal of Environmental Science and Health Part A 42: 641-647 (2007).

26. Zekker I, Rikmann E, Kroon K, Mandel A, Mihkelson J and Tenno T, Ameliorating nitrite inhibition in a low-temperature nitritation-anammox MBBR using bacterial intermediate nitric oxide. International Journal of Environmental Science and Technology 14: 2343-2356 (2017).

27. Raudkivi M, Zekker I, Rikmann E, Vabamäe P, Kroon K and Tenno T, Nitrite inhibition and limitation-the effect of nitrite spiking on anammox biofilm, suspended and granular biomass. Water Science and Technology 75: 313-321 (2017).

28. Lee L, Ong $\mathrm{S}$ and $\mathrm{Ng} \mathrm{W}$, Biofilm morphology and nitrification activities: recovery of nitrifying biofilm particles covered with heterotrophic outgrowth. Bioresource technology 95: 209-214 (2004).

29. Walter B, Haase $\mathrm{C}$ and Räbiger N, Combined nitrification/denitrification in a membrane reactor. Water research 39: 2781-2788 (2005).

30. Khin $\mathrm{T}$ and Annachhatre AP, Novel microbial nitrogen removal processes. Biotechnology Advances 22: 519-532 (2004).

31. Schmidt I, Sliekers O, Schmid M, Bock E, Fuerst J, Kuenen JG, Jetten MS and Strous M, New concepts of microbial treatment processes for the nitrogen removal in wastewater. FEMS microbiology reviews 27: 481-492 (2003).

32. Rikmann E, Zekker I, Tomingas M, Tenno T, Loorits L, Vabamäe P, Mandel A, Raudkivi M, Daija L and Kroon K, Sulfate-reducing anammox for sulfate and nitrogen containing wastewaters. Desalination and Water Treatment 57: $3132-$ 3141 (2016).

33. Rikmann E, Zekker I, Tomingas M, Vabamäe P, Kroon K, Saluste A, Tenno T, Menert A, Loorits L and $\mathrm{dC}$ Rubin SS, Comparison of sulfate-reducing and conventional Anammox upflow anaerobic sludge blanket reactors. Journal of bioscience and bioengineering 118: 426-433 (2014).

34. Zekker I, Rikmann E, Mandel A, Kroon K, Seiman A, Mihkelson J, Tenno T and Tenno T, Step-wise temperature decreasing cultivates a biofilm with high nitrogen removal rates at $9 \mathrm{C}$ in short-term anammox biofilm tests. Environmental technology 37: 1933-1946 (2016). 
35. Shalini SS and Joseph K, Nitrogen management in landfill leachate: application of SHARON, ANAMMOX and combined SHARON-ANAMMOX process. Waste Management 32: 2385-2400 (2012).

36. Barwal A and Chaudhary R, To study the performance of biocarriers in moving bed biofilm reactor (MBBR) technology and kinetics of biofilm for retrofitting the existing aerobic treatment systems: a review. Reviews in Environmental Science and Bio/Technology 13: 285-299 (2014).

37. Jahren SJ, Rintala JA and Ødegaard H, Aerobic moving bed biofilm reactor treating thermomechanical pulping whitewater under thermophilic conditions. Water Research 36: 1067-1075 (2002).

38. Kermani M, Bina B, Movahedian H, Amin MM and Nikaeen M, Biological phosphorus and nitrogen removal from wastewater using moving bed biofilm process. Iranian journal of biotechnology 7: 19-27 (2009).

39. McQuarrie JP and Boltz JP, Moving Bed Biofilm Reactor Technology: Process Applications, Design, and Performance. Water Environment Research 83: 560575 (2011).

40. Vaidhegi K, Treatment of Bagasse based pulp and paper industry effluent using moving bed biofilm reactor. Int J Chemtech Res 5: 1313-1319 (2013).

41. Forrest D, Delatolla R and Kennedy K, Carrier effects on tertiary nitrifying moving bed biofilm reactor: An examination of performance, biofilm and biologically produced solids. Environmental Technology (United Kingdom) 37: 662-671 (2016).

42. Houda N, Abdelwaheb C, Asma BR, Ines M, Ahmed L and Abdennaceur H, Tertiary Nitrification Using Moving-Bed Biofilm Reactor: A Case Study in Tunisia. Current Microbiology 70: 602-609 (2015).

43. Calderón K, Martín-Pascual J, Poyatos JM, Rodelas B, González-Martínez A and González-López J, Comparative analysis of the bacterial diversity in a lab-scale moving bed biofilm reactor (MBBR) applied to treat urban wastewater under different operational conditions. Bioresource Technology 121: 119-126 (2012).

44. Ødegaard H, Innovations in wastewater treatment:-the moving bed biofilm process. Water Science and Technology 53: 17-33 (2006).

45. Hem LJ, Rusten B and Ødegaard H, Nitrification in a moving bed biofilm reactor. Water Research 28: 1425-1433 (1994).

46. Schubert R, Boulestreau M, Christensson M and Lesjean B, Novel wastewater process scheme for maximum COD extraction: high load MBBR followed by microsieve filtration, in 9th International Conference on Biofilm Reactors, May, pp. 28-31 (2013).

47. Otawa K, Asano R, Ohba Y, Sasaki T, Kawamura E, Koyama F, Nakamura S and Nakai Y, Molecular analysis of ammonia-oxidizing bacteria community in intermittent aeration sequencing batch reactors used for animal wastewater treatment. Environmental Microbiology 8: 1985-1996 (2006).

48. Helness $\mathrm{H}$ and Ødegaard $\mathrm{H}$, Biological phosphorus and nitrogen removal in a sequencing batch moving bed biofilm reactor. Water science and technology 43 : 233-240 (2001). 
49. Young B, Banihashemi B, Forrest D, Kennedy K, Stintzi A and Delatolla R, Meso and micro-scale response of post carbon removal nitrifying MBBR biofilm across carrier type and loading. Water Research 91: 235-243 (2016).

50. Masłon A and Tomaszek JA, A study on the use of the BioBall ${ }^{\circledR}$ as a biofilm carrier in a sequencing batch reactor. Bioresource Technology 196: 577-585 (2015).

51. Li C, Felz S, Wagner M, Lackner S and Horn H, Investigating biofilm structure developing on carriers from lab-scale moving bed biofilm reactors based on light microscopy and optical coherence tomography. Bioresource Technology 200: 128-136 (2016).

52. Martín-Pascual J, López-López C, Cerdá A, González-López J, Hontoria E and Poyatos JM, Comparative Kinetic Study of Carrier Type in a Moving Bed System Applied to Organic Matter Removal in Urban Wastewater Treatment. Water, Air, \& Soil Pollution 223: 1699-1712 (2012).

53. Zhang X, Chen X, Zhang C, Wen H, Guo W and Ngo HH, Effect of filling fraction on the performance of sponge-based moving bed biofilm reactor. Bioresource Technology 219: $762-767$ (2016).

54. Deng L, Guo W, Ngo HH, Zhang X, Wang XC, Zhang Q and Chen R, New functional biocarriers for enhancing the performance of a hybrid moving bed biofilm reactor-membrane bioreactor system. Bioresource Technology 208: 87-93 (2016).

55. Nguyen TT, Ngo HH, Guo W, Johnston A and Listowski A, Effects of sponge size and type on the performance of an up-flow sponge bioreactor in primary treated sewage effluent treatment. Bioresource Technology 101: 1416-1420 (2010).

56. Chen X, Kong L, Wang X, Tian S and Xiong Y, Accelerated start-up of moving bed biofilm reactor by using a novel suspended carrier with porous surface. Bioprocess and Biosystems Engineering 38: 273-285 (2015).

57. Chu L and Wang J, Nitrogen removal using biodegradable polymers as carbon source and biofilm carriers in a moving bed biofilm reactor. Chemical Engineering Journal 170: 220-225 (2011).

58. Chu L and Wang J, Comparison of polyurethane foam and biodegradable polymer as carriers in moving bed biofilm reactor for treating wastewater with a low $\mathrm{C} / \mathrm{N}$ ratio. Chemosphere 83: 63-68 (2011).

59. Di Trapani D, Mannina G, Torregrossa M and Viviani G, Hybrid moving bed biofilm reactors: a pilot plant experiment. Water Science and Technology 57: 1539-1545 (2008).

60. Rusten B, Hem LJ and Ødegaard H, Nitrification of municipal wastewater in moving-bed biofilm reactors. Water Environment Research 67: 75-86 (1995).

61. Monfet E, Aubry G and Ramirez AA, Nutrient removal and recovery from digestate: a review of the technology. Biofuels 9: 247-262 (2018).

62. Szatkowska B, Cema G, Plaza E, Trela J and Hultman B, A one-stage system with partial nitritation and Anammox processes in the moving-bed biofilm reactor. Water Science and Technology 55: 19-26 (2007). 
63. Szatkowska B, Plaza E, Trela J, Hultman B and Bosander J, Combined partial nitritation and Anammox biofilm system as a sustainable solution for supernatant treatment. Water Practice and Technology 2: wpt2007005 (2007).

64. Leiknes $\mathrm{T}$ and Ødegaard $\mathrm{H}$, The development of a biofilm membrane bioreactor. Desalination 202: 135-143 (2007).

65. Shanahan JW and Semmens MJ, Alkalinity and $\mathrm{pH}$ effects on nitrification in a membrane aerated bioreactor: An experimental and model analysis. Water Research 74: 10-22 (2015).

66. Casey E, Glennon B and Hamer G, Review of membrane aerated biofilm reactors. Resources, Conservation and Recycling 27: $203-215$ (1999).

67. Hibiya K, Terada A, Tsuneda S and Hirata A, Simultaneous nitrification and denitrification by controlling vertical and horizontal microenvironment in a membrane-aerated biofilm reactor. Journal of biotechnology 100: 23-32 (2003).

68. Syron E and Casey E, Membrane Aerated Biofilm Reactors. Encyclopedia of Membrane Science and Technology (2013).

69. Wang R, Xiao F, Wang Y and Lewandowski Z, Determining the optimal transmembrane gas pressure for nitrification in membrane-aerated biofilm reactors based on oxygen profile analysis. Applied Microbiology and Biotechnology 100: 7699-7711 (2016).

70. Tian H, Zhang H, Li P, Sun L, Hou F and Li B, Treatment of pharmaceutical wastewater for reuse by coupled membrane-aerated biofilm reactor (MABR) system. RSC Advances 5: 69829-69838 (2015).

71. Downing LS and Nerenberg R, Effect of oxygen gradients on the activity and microbial community structure of a nitrifying, membrane-aerated biofilm. Biotechnology and Bioengineering 101: 1193-1204 (2008).

72. Hwang JH, Cicek $\mathrm{N}$ and Oleszkiewicz J, Effect of loading rate and oxygen supply on nitrification in a non-porous membrane biofilm reactor. Water Research 43: 3301-3307 (2009).

73. Li M, Du C, Liu J, Quan X, Lan M and Li B, Mathematical modeling on the nitrogen removal inside the membrane-aerated biofilm dominated by ammoniaoxidizing archaea (AOA): Effects of temperature, aeration pressure and COD/N ratio. Chemical Engineering Journal 338: 680-687 (2018).

74. Syron E, Semmens MJ and Casey E, Performance analysis of a pilot-scale membrane aerated biofilm reactor for the treatment of landfill leachate. Chemical Engineering Journal 273: 120-129 (2015).

75. Terada A, Yamamoto T, Igarashi R, Tsuneda S and Hirata A, Feasibility of a membrane-aerated biofilm reactor to achieve controllable nitrification. Biochemical Engineering Journal 28: 123-130 (2006).

76. Lackner S, Terada A, Horn H, Henze M and Smets BF, Nitritation performance in membrane-aerated biofilm reactors differs from conventional biofilm systems. Water Research 44: 6073-6084 (2010).

77. Brindle $\mathrm{K}$ and Stephenson T, Nitrification in a bubbleless oxygen mass transfer membrane bioreactor. Water Science and Technology 34: 261-267 (1996).

78. Brindle K, Stephenson T and Semmens MJ, Nitrification and oxygen utilisation in a membrane aeration bioreactor. Journal of Membrane Science 144: 197-209 (1998).

This article is protected by copyright. All rights reserved. 
79. Downing LS and Nerenberg R, Effect of oxygen gradients on the activity and microbial community structure of a nitrifying, membrane-aerated biofilm. Biotechnology and Bioengineering 101: 1193-1204 (2008).

80. Yeh S-J and Jenkins CR, Pure oxygen fixed film reactor. Journal of the Environmental Engineering Division 104: 611-623 (1978).

81. Pankhania M, Stephenson $\mathrm{T}$ and Semmens MJ, Hollow fibre bioreactor for wastewater treatment using bubbleless membrane aeration. Water research 28: 2233-2236 (1994).

82. Suzuki Y, Miyahara S and Takeishi K, Oxygen supply method using gaspermeable film for wastewater treatment. Water Science and Technology 28: 243250 (1993).

83. Lin H, Ong SL, Ng WJ and Khan E, Performance of a biofilm airlift suspension reactor for synthetic wastewater treatment. Journal of Environmental Engineering 130: $26-36$ (2004).

84. Van Benthum W, Garrido-Fernández J, Tijhuis L, Van Loosdrecht M and Heijnen $\mathrm{J}$, Formation and detachment of biofilms and granules in a nitrifying biofilm airlift suspension reactor. Biotechnology progress 12: 764-772 (1996).

85. Van Benthum W, Van Loosdrecht $\mathrm{M}$ and Heijnen J, Control of heterotrophic layer formation on nitrifying biofilms in a biofilm airlift suspension reactor. Biotechnology and bioengineering 53: 397-405 (1997).

86. Garrido JM, van Benthum WAJ, van Loosdrecht MCM and Heijnen JJ, Influence of dissolved oxygen concentration on nitrite accumulation in a biofilm airlift suspension reactor. Biotechnology and Bioengineering 53: 168-178 (1997).

87. Picioreanu C, van Loosdrecht MCM and Heijnen JJ, Modelling the effect of oxygen concentration on nitrite accumulation in a biofilm airlift suspension reactor. Water Science and Technology 36: 147-156 (1997).

88. Wilderer PA, Röske I, Ueberschär A and Davids L, Continuous flow and sequenced batch operation of biofilm reactors: A comparative study of shock loading responses. Biofouling 6: 295-304 (1993).

89. Zou J, Li J, Ni Y and Wei S, Enhancing nitrogen removal from low carbon to nitrogen ratio wastewater by using a novel sequencing batch biofilm reactor. Journal of Environmental Sciences 50: 32-37 (2016).

90. Li K, Fang F, Guo J, Chen Y, Yang J and Wei H, Performance of one-stage autotrophic nitrogen removal in a biofilm reactor with low $\mathrm{C} / \mathrm{N}$ ratio. Environmental Technology 36: 1819-1827 (2015).

91. Hwang B, Lu Q, de Toledo RA and Shim H, Enhanced nitrogen removal from sludge reject water by methanol addition using sequencing batch biofilm reactor. Desalination and Water Treatment 57: 8730-8738 (2016).

92. Jin Y, Ding D, Feng C, Tong S, Suemura T and Zhang F, Performance of sequencing batch biofilm reactors with different control systems in treating synthetic municipal wastewater. Bioresource Technology 104: 12-18 (2012).

93. Kong Q, Zhang J, Miao M, Tian L, Guo N and Liang S, Partial nitrification and nitrous oxide emission in an intermittently aerated sequencing batch biofilm reactor. Chemical Engineering Journal 217: 435-441 (2013).

This article is protected by copyright. All rights reserved. 
94. Yin J, Zhang P, Li F, Li G and Hai B, Simultaneous biological nitrogen and phosphorus removal with a sequencing batch reactor-biofilm system. International Biodeterioration \& Biodegradation 103: 221-226 (2015).

95. Gieseke A, Arnz P, Amann R and Schramm A, Simultaneous P and N removal in a sequencing batch biofilm reactor: insights from reactor- and microscale investigations. Water Research 36: 501-509 (2002).

96. Prosser J, Autotrophic nitrification in bacteria. Advances in microbial physiology 30: 125-181 (1990).

97. Gieseke A, Arnz P, Amann R and Schramm A, Simultaneous P and N removal in a sequencing batch biofilm reactor: insights from reactor-and microscale investigations. Water Research 36: 501-509 (2002).

98. Bortone G, Malaspina F, Stante L and Tilche A, Biological nitrogen and phosphorus removal in an anaerobic/anoxic sequencing batch reactor with separated biofilm nitrification. Water Science and Technology 30: 303-313 (1994).

99. Garzon-Zuniga MA and Gonzalez-Martinez S, Biological phosphate and nitrogen removal in a biofilm sequencing batch reactor. Water Science and Technology 34: 293-301 (1996).

100. Wei D, Zhang K, Ngo HH, Guo W, Wang S, Li J, Han F, Du B and Wei Q, Nitrogen removal via nitrite in a partial nitrification sequencing batch biofilm reactor treating high strength ammonia wastewater and its greenhouse gas emission. Bioresource Technology 230: 49-55 (2017).

101. Xiao H, Yang P, Peng H, Zhang Y, Deng S and Zhang X, Nitrogen removal from livestock and poultry breeding wastewaters using a novel sequencing batch biofilm reactor. Water Science and Technology 62: 2599-2606 (2010).

102. Dulkadiroglu H, Seckin G and Orhon D, Modeling nitrate concentrations in a moving bed sequencing batch biofilm reactor using an artificial neural network technique. Desalination and Water Treatment 54: 2496-2503 (2015).

103. Tan K-C, Seng C-E, Lim P-E, Oo C-W, Lim J-W and Kew S-L, Alteration of moving bed sequencing batch reactor operational strategies for the enhancement of nitrogen removal from stabilized landfill leachate. Desalination and Water Treatment 57: 15979-15988 (2016).

104. Pandey S and Sarkar S, Anaerobic treatment of wastewater using a two-stage packed-bed reactor containing polyvinyl alcohol gel beads as biofilm carrier. Journal of Environmental Chemical Engineering 5: 1575-1585 (2017).

105. Kim J, Song I, Lee S, Kim P, Oh H, Park J and Choung Y, Decompostion of pharmaceuticals (sulfamethazine and sulfathiazole) using oxygen-based membrane biofilm reactor. Desalination 250: 751-756 (2010).

106. Brosseau C, Émile B, Labelle M-A, Laflamme É, Dold PL and Comeau Y, Compact secondary treatment train combining a lab-scale moving bed biofilm reactor and enhanced flotation processes. Water Research 106: 571-582 (2016).

107. Li J, Xing X-H and Wang B-Z, Characteristics of phosphorus removal from wastewater by biofilm sequencing batch reactor (SBR). Biochemical Engineering Journal 16: 279-285 (2003).

108. Zekker I, Rikmann E, Tenno T, Saluste A, Tomingas M, Menert A, Loorits L, Lemmiksoo $\mathrm{V}$ and Tenno $\mathrm{T}$, Achieving nitritation and anammox enrichment in a

This article is protected by copyright. All rights reserved. 
single moving-bed biofilm reactor treating reject water. Environmental technology 33: 703-710 (2012).

109. Vadivelu VM, Keller J and Yuan Z, Effect of free ammonia on the respiration and growth processes of an enriched Nitrobacter culture. Water Research 41: 826-834 (2007).

110. Pellicer-Nàcher C, Franck S, Gülay A, Ruscalleda M, Terada A, Al-Soud WA, Hansen MA, Sørensen SJ and Smets BF, Sequentially aerated membrane biofilm reactors for autotrophic nitrogen removal: microbial community composition and dynamics. Microbial Biotechnology 7: 32-43 (2014).

111. Torresi E, Fowler SJ, Polesel F, Bester K, Andersen HR, Smets BF, Plósz BG and Christensson M, Biofilm Thickness Influences Biodiversity in Nitrifying MBBRs-Implications on Micropollutant Removal. Environmental Science \& Technology 50: 9279-9288 (2016).

112. Nerenberg R, The membrane-biofilm reactor (MBfR) as a counter-diffusional biofilm process. Current Opinion in Biotechnology 38: 131-136 (2016).

113. Aybar M, Pizarro G, Boltz JP, Downing L and Nerenberg R, Energy-efficient wastewater treatment via the air-based, hybrid membrane biofilm reactor (hybrid MfBR). Water Science and Technology 69: 1735-1741 (2014).

114. Rosso D, Larson LE and Stenstrom MK, Aeration of large-scale municipal wastewater treatment plants: state of the art. Water Science and Technology 57: 973-978 (2008).

115. Lin J, Zhang P, Li G, Yin J, Li J and Zhao X, Effect of COD/N ratio on nitrogen removal in a membrane-aerated biofilm reactor. International Biodeterioration \& Biodegradation 113: $74-79$ (2016).

116. Garrido J, Van Benthum W, Van Loosdrecht M and Heijnen J, Influence of dissolved oxygen concentration on nitrite accumulation in a biofilm airlift suspension reactor. Biotechnology and bioengineering 53: 168-178 (1997).

117. Helness $\mathrm{H}$ and Ødegaard $\mathrm{H}$, Biological phosphorus removal in a sequencing batch moving bed biofilm reactor. Water Science and Technology 40: 161-168 (1999).

118. Andrade do Canto CS, Rodrigues JAD, Ratusznei SM, Zaiat M and Foresti E, Feasibility of nitrification/denitrification in a sequencing batch biofilm reactor with liquid circulation applied to post-treatment. Bioresource Technology 99: 644-654 (2008).

119. Beun JJ, van Loosdrecht MCM and Heijnen JJ, Aerobic granulation in a sequencing batch airlift reactor. Water Research 36: $702-712$ (2002).

120. Tang C-J, Zheng P, Wang C-H, Mahmood Q, Zhang J-Q, Chen X-G, Zhang L and Chen J-W, Performance of high-loaded ANAMMOX UASB reactors containing granular sludge. Water Research 45: 135-144 (2011).

121. Daija L, Selberg A, Rikmann E, Zekker I, Tenno T and Tenno T, The influence of lower temperature, influent fluctuations and long retention time on the performance of an upflow mode laboratory-scale septic tank. Desalination and Water Treatment 57: 18679-18687 (2016).

122. Zhang Z, Zhou J, Wang J, Guo $\mathrm{H}$ and Tong J, Integration of nitrification and denitrifying dephosphatation in airlift loop sequencing batch biofilm reactor. Process Biochemistry 41: 599-608 (2006).

This article is protected by copyright. All rights reserved. 
123. Kim $\mathrm{K}$, The characteristic of the sequencing batch reactor (SBR), anaerobic sequencing batch reactor (ASBR) and sequencing batch biofilm reactor (SBBR). (2010).

124. Sirianuntapiboon $\mathrm{S}$ and Hongsrisuwan $\mathrm{T}$, Removal of $\mathrm{Zn} 2+$ and $\mathrm{Cu} 2+$ by a sequencing batch reactor (SBR) system. Bioresource technology 98: 808-818 (2007).

125. Sarti A, Fernandes BS, Zaiat $M$ and Foresti E, Anaerobic sequencing batch reactors in pilot-scale for domestic sewage treatment. Desalination 216: 174-182 (2007).

126. Kawan JA, Hasan HA, Suja F, JAAFAR OB and Abd-Rahman R, A review on sewage treatment and polishing using moving bed bioreactor (Mbbr). Journal of Engineering Science and Technology 11: 1098-1120 (2016).

127. Borkar R, Gulhane M and Kotangale A, Moving bed biofilm reactor-a new perspective in wastewater treatment. IOSR Journal of Environmental Science, Toxicology and Food Technology 6: 15-21 (2013).

128. Sriwiriyarat $\mathrm{T}$ and Randall CW, Evaluation of integrated fixed film activated sludge wastewater treatment processes at high mean cells residence time and low temperatures. Journal of environmental engineering 131: 1550-1556 (2005).

129. Fang $\mathrm{HH}$, Environmental Anaerobic Technology: applications and new developments. World Scientific (2010).

130. Morse A, Jackson A and Rainwater K, Nitrification using a membrane-aerated biological reactor. SAE Technical Paper (2003).

131. Ruiz Careri MN, Advantages and disadvantages of microporous membranes in a hollow fiber bioreactor for space applications (2005).

132. Ercan D and Demirci A, Current and future trends for biofilm reactors for fermentation processes. Critical reviews in biotechnology 35: 1-14 (2015).

133. Zinatizadeh AAL and Ghaytooli E, Simultaneous nitrogen and carbon removal from wastewater at different operating conditions in a moving bed biofilm reactor (MBBR): Process modeling and optimization. Journal of the Taiwan Institute of Chemical Engineers 53: 98-111 (2015).

134. Lee W-N, Kang I-J and Lee C-H, Factors affecting filtration characteristics in membrane-coupled moving bed biofilm reactor. Water Research 40: 1827-1835 (2006).

135. Zhai S, Zhao Y, Ji M and Qi W, Simultaneous removal of nitrate and chromate in groundwater by a spiral fiber based biofilm reactor. Bioresource Technology 232: 278-284 (2017).

136. Tian H-L, Zhao J-Y, Zhang H-Y, Chi C-Q, Li B-A and Wu X-L, Bacterial community shift along with the changes in operational conditions in a membraneaerated biofilm reactor. Applied Microbiology and Biotechnology 99: 3279-3290 (2015).

137. Jiang Y, Wang H, Shang Y and Yang K, Simultaneous removal of aniline, nitrogen and phosphorus in aniline-containing wastewater treatment by using sequencing batch reactor. Bioresource Technology 207: 422-429 (2016).

138. Seetha N, Bhargava R and Kumar P, Effect of organic shock loads on a two-stage activated sludge-biofilm reactor. Bioresource Technology 101: 3060-3066 (2010).

This article is protected by copyright. All rights reserved. 
139. Lee HS, Park SJ and Yoon TI, Wastewater treatment in a hybrid biological reactor using powdered minerals: effects of organic loading rates on COD removal and nitrification. Process Biochemistry 38: 81-88 (2002).

140. Zhu Y, Zhang Y, Ren H-q, Geng J-j, Xu K, Huang $\mathrm{H}$ and Ding L-l, Physicochemical characteristics and microbial community evolution of biofilms during the start-up period in a moving bed biofilm reactor. Bioresource Technology 180: 345-351 (2015).

141. Zhou P, He J and Qian Y, Influence of Hydrodynamics on the Performance of a Biofilm Airlift Suspension Reactor. Journal of Environmental Engineering 131: 874-882 (2005). 
Table 1: Overview of cultures used in different types of nitrifying bioreactors with P-

value $(<0.05)$

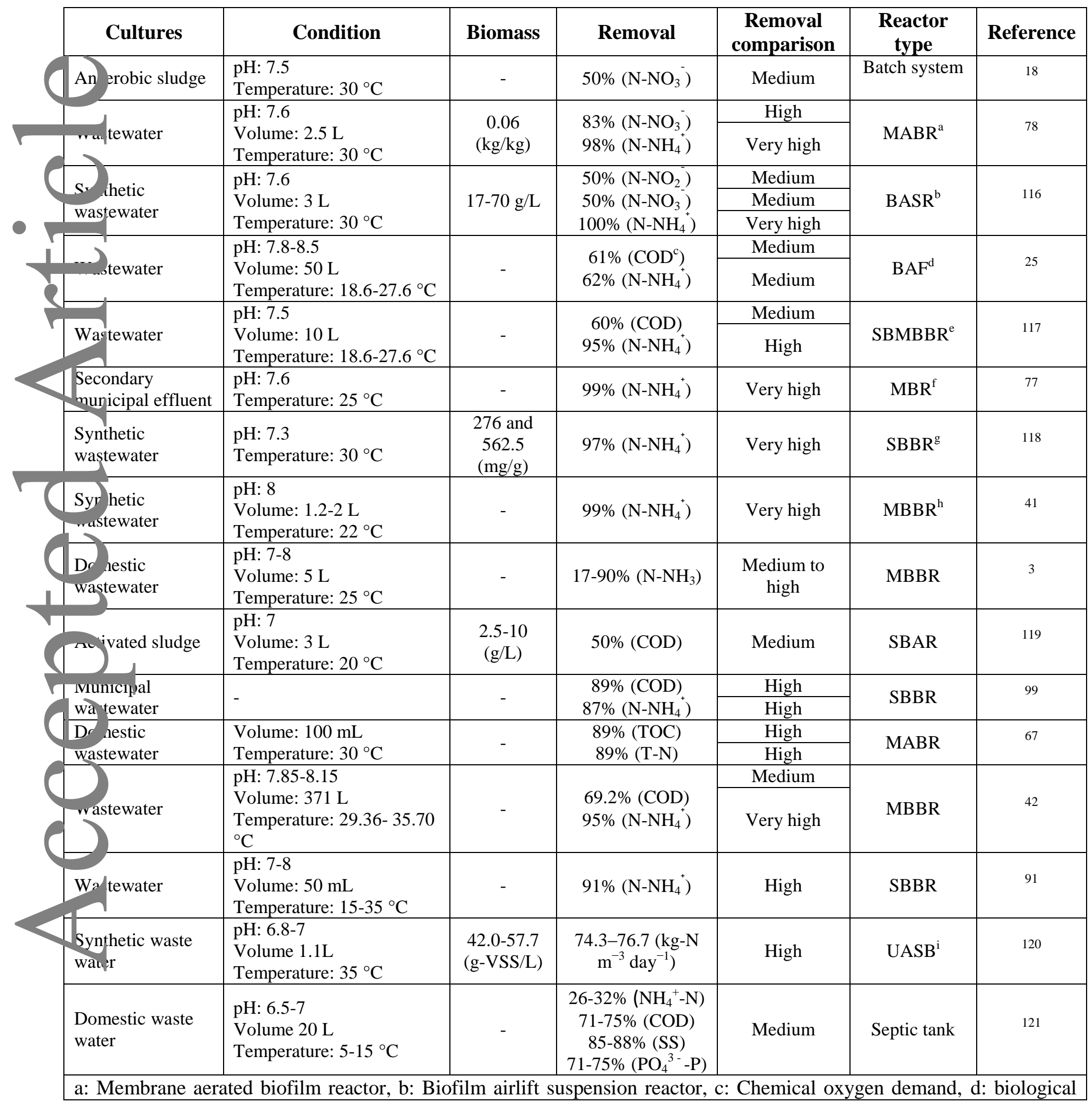

This article is protected by copyright. All rights reserved. 
aerated filter, e: sequencing batch moving bed biofilm reactor, f: membrane bioreactors, g: Sequencing batch biofilm reactor, h: Moving bed biofilm reactor, i: upflow anaerobic sludge bed reactor

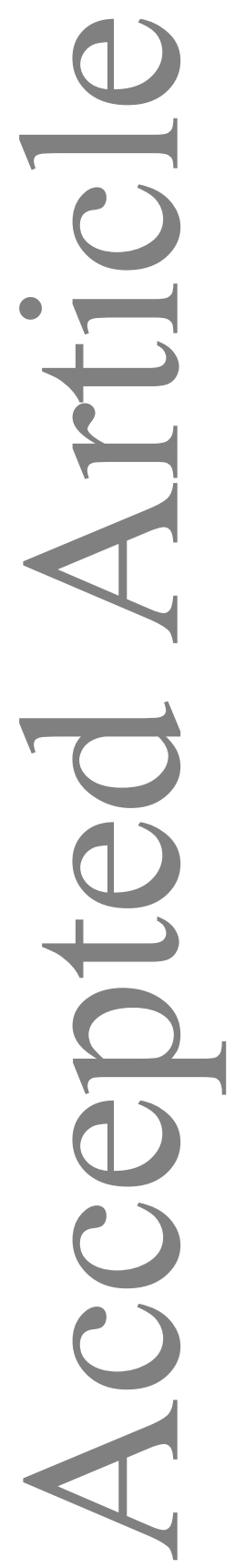

This article is protected by copyright. All rights reserved. 
Table 3: Effect of different operation condition and their related result with P-value (<

\begin{tabular}{|c|c|c|c|c|c|c|c|}
\hline $\begin{array}{c}\text { DO } \\
\text { concentration }\end{array}$ & HRT & $\mathbf{p H}$ & Temperature & $\begin{array}{c}\text { COD } \\
\text { removal }\end{array}$ & $\begin{array}{c}\text { TN } \\
\text { removal }\end{array}$ & $\begin{array}{c}\text { TP } \\
\text { removal }\end{array}$ & Reference \\
\hline $\mathrm{mg} / \mathrm{L}$ & $\mathrm{h}$ & - & ${ }^{\circ} \mathrm{C}$ & $\%$ & $\%$ & $\%$ & - \\
\hline 4 & 12 & $6.5-7.5$ & & 86 & 26 & 0 & ${ }^{133}$ \\
\hline 5 & 10 & $6.5-7.5$ & 25 & 98 & - & - & ${ }^{134}$ \\
\hline- & 8 & 7 & $25-28$ & $82.2-95.6$ & $97-100$ & - & ${ }^{135}$ \\
\hline $1-4$ & 12 & $4.5-7$ & 20 & 81.6 & 75.8 & - & ${ }^{136}$ \\
\hline 5.5 & 12 & - & 30 & 96.3 & 84.9 & 93.9 & ${ }^{137}$ \\
\hline $3-3.5$ & - & $7.9-8.3$ & $25-35$ & 72 & 31 & - & ${ }^{138}$ \\
\hline $2.5-3.5$ & - & $7.6-7.8$ & 20 & 93 & - & - & ${ }^{139}$ \\
\hline $3.0-4.0$ & 11.9 & $7.3-7.5$ & $30-32$ & 85 & 83 & - & \\
\hline
\end{tabular}

DO: Dissolved Oxygen; HRT: Hydraulic Residence Time; COD: Chemical Oxygen

Demand; TN: Total Nitrogen; TP: Total Phosphorus

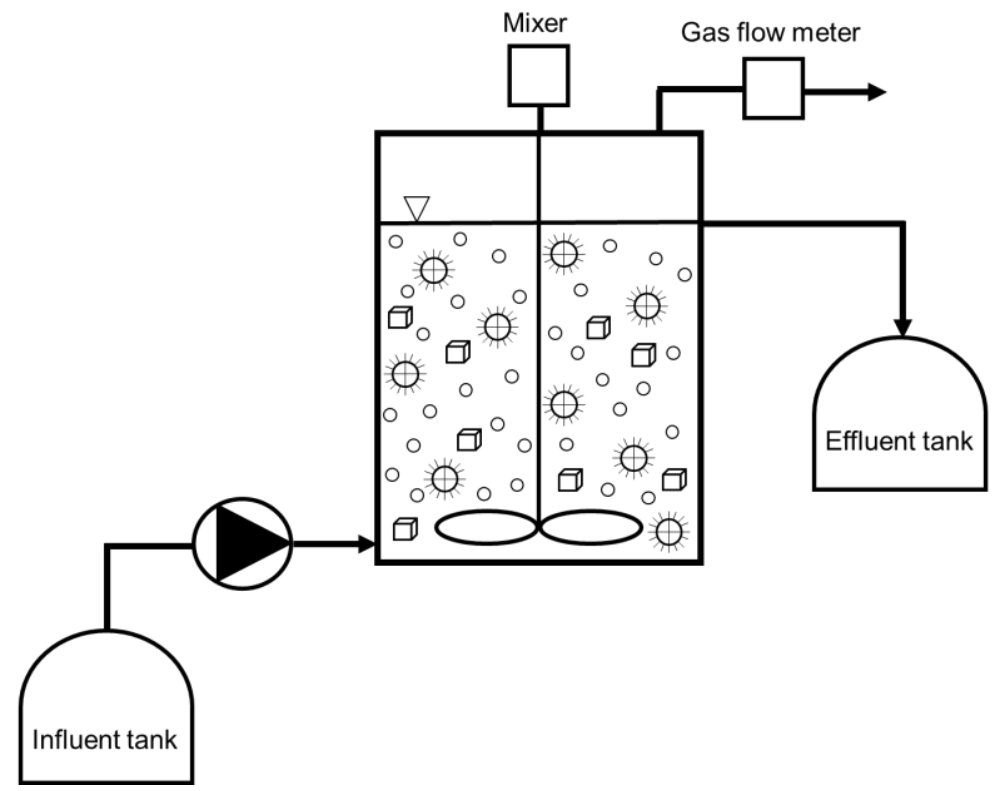

Figure 1: Schematic diagram of the moving bed biofilm reactor

The moving bed biofilm reactor may have one or more stages. The bacteria stay in the duty tank because the carriers are protected by screens. The bacteria grow on the surface of the carriers and break down the organic materials in wastewater. The carriers are kept 
in motion by an aeration system. The excess bacteria will be separated from the carriers and will flow with the effluent to the final separator ${ }^{140}$.

This article is protected by copyright. All rights reserved. 


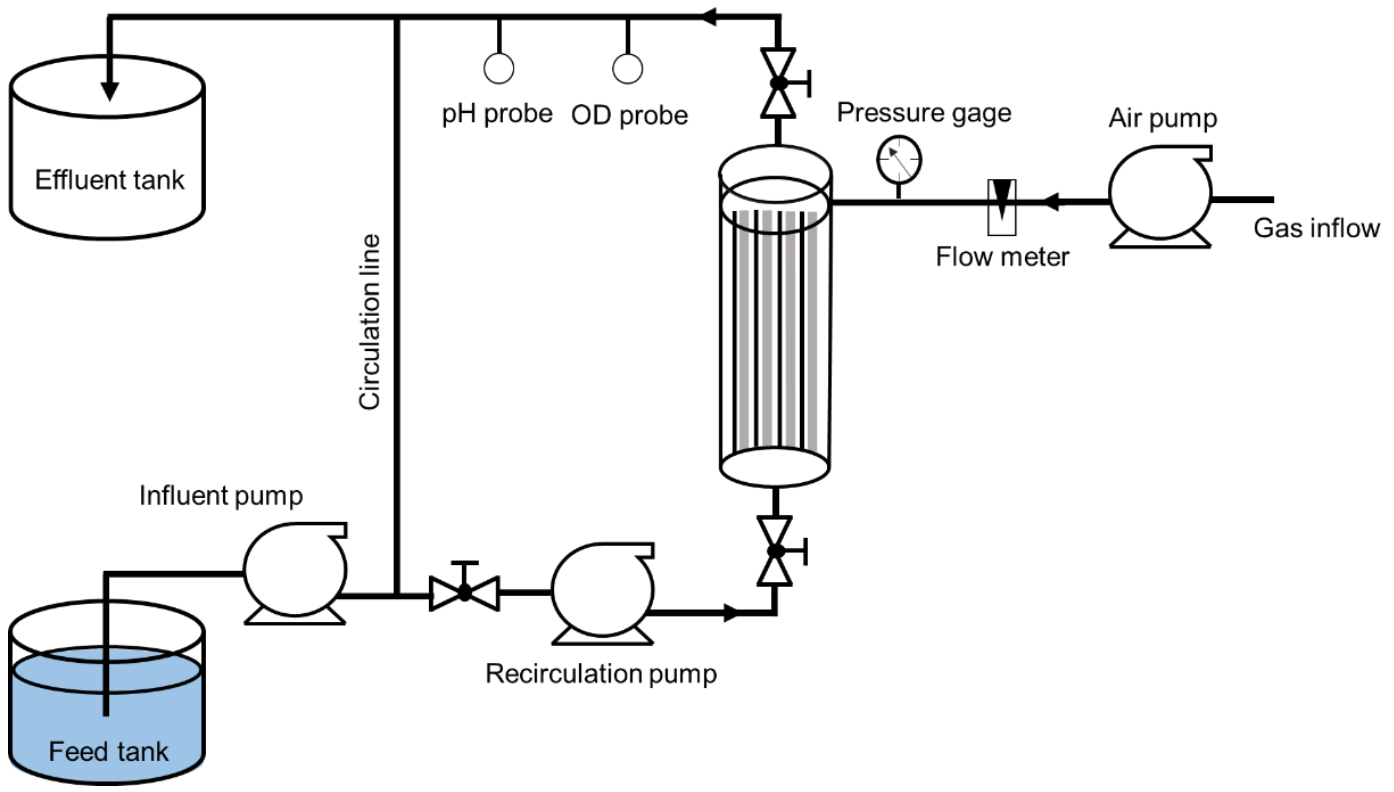

Figure 2: Schematic diagram of the membrane-aerated biofilm reactor

In the membrane-aerated biofilm reactor, membranes are immersed vertically into the reactors. First, the reactor is filled with distilled water and nitrogen is sparged into the reactor in order to decrease dissolved oxygen. Then, aeration is started through the hollow-fiber membrane ${ }^{75}$. 


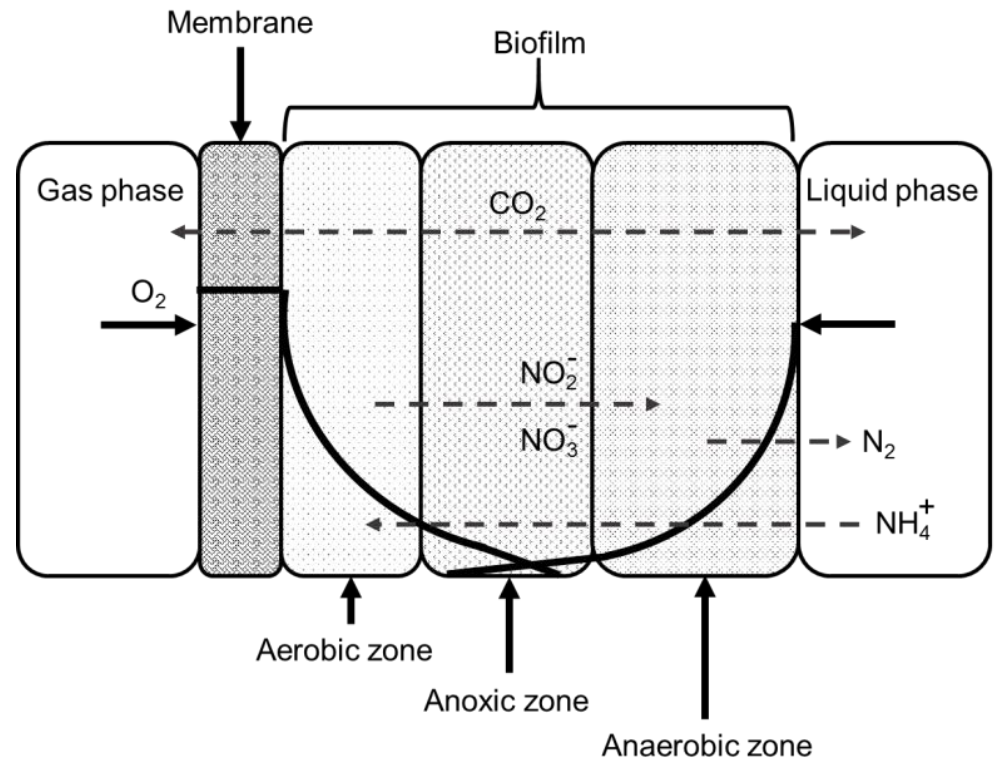

Figure 3: Schematic of oxygen profile in membrane-aerated biofilm

This article is protected by copyright. All rights reserved. 


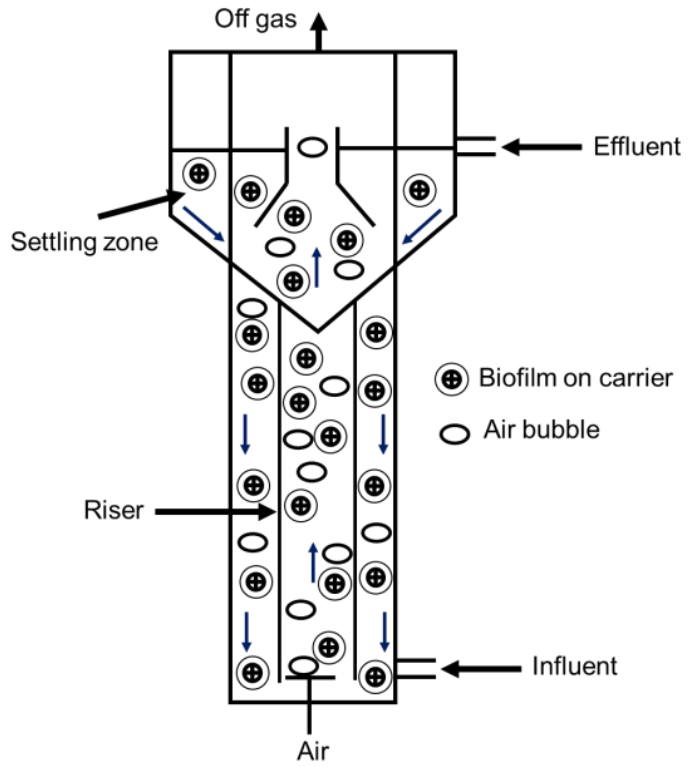

Figure 4: Schematic diagram of the biofilm airlift suspension reactor

The biofilm airlift suspension reactor has three parts: riser, down-comer, and three-phase separator. Inertial materials, such as activated carbon are used as carriers to for growth of microorganisms. Upon initial aeration through the riser, the density difference between the riser and down-comer, results in the internal circulation of carriers, wastewater, and bubbles. Carriers are uniformly distributed through the reactor and bacteria have close contact with wastewater to degrade organic compounds ${ }^{141}$. 


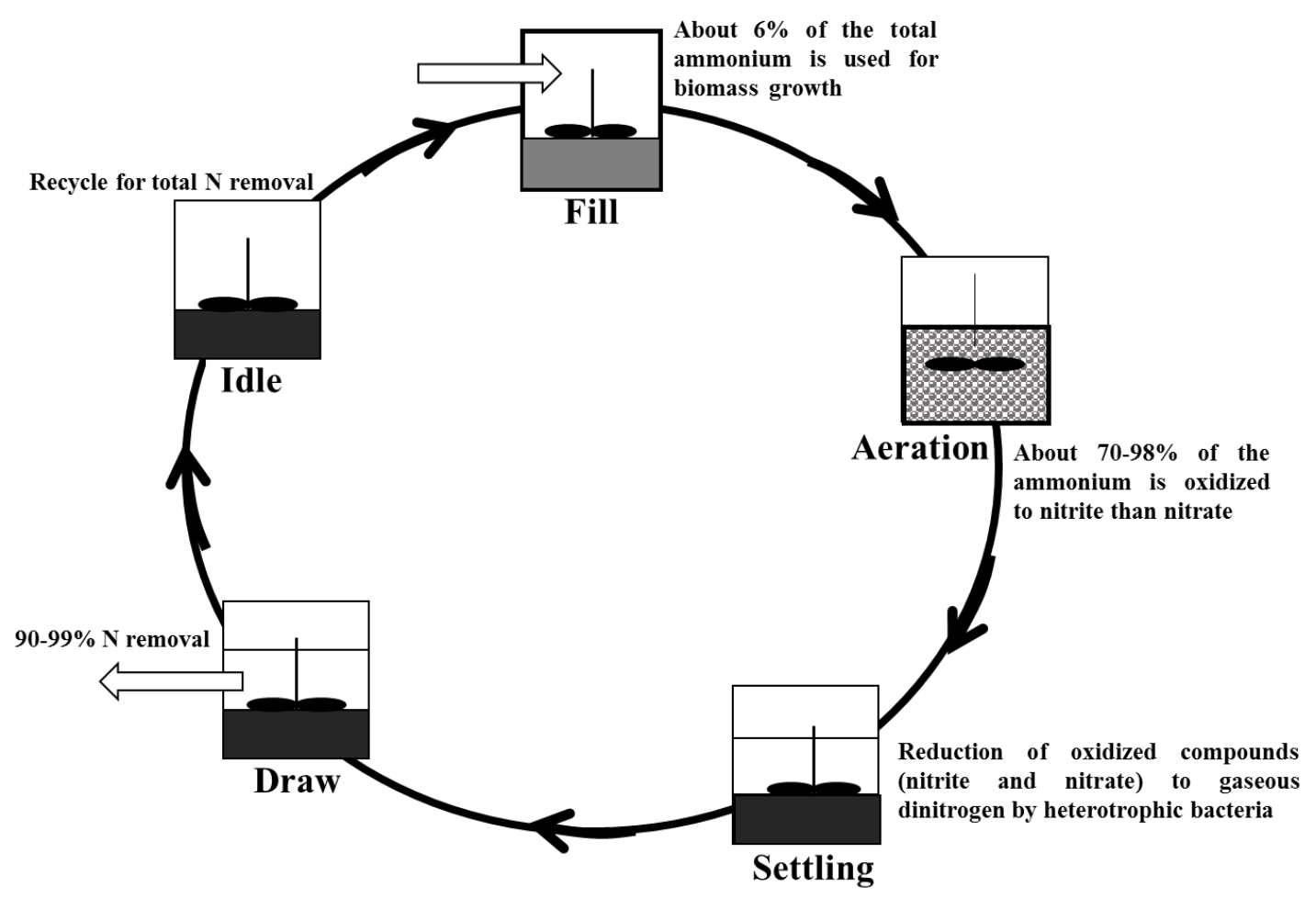

Figure 5: Schematic of sequencing batch reactor mechanism

This article is protected by copyright. All rights reserved. 